ISSN 1392-3196 / e-ISSN 2335-8947

Zemdirbyste-Agriculture, vol. 108, No. 3 (2021), p. 203-208

DOI 10.13080/z-a.2021.108.026

\title{
Optimization of nitrogen fertilisation of winter wheat
}

\author{
Gediminas STAUGAITIS, Kazimieras POŠKUS, Zita BRAZIENĖ, \\ Virgilijus PALTANAVIČIUS \\ Lithuanian Research Centre for Agriculture and Forestry \\ Klausučių 20, Klausučiai, Vilkaviškis distr., Lithuania \\ E-mail: kazimieras.poskus@lammc.lt
}

\begin{abstract}
The experiment with winter wheat (Triticum aestivum L.) grown under intensive cultivation technology was carried out in 2018-2020 on a Calcaric Luvisol. The aim of the research was to determine the optimal rates of nitrogen $(\mathrm{N})$ fertilisers for winter wheat linking them with the grain yield and quality and the concentration of mineral $\mathrm{N}$ in the soil.

The results of the experiment showed that $\mathrm{N}$ fertilisers improved the nutritional value and technological properties of winter wheat grain. Fertilisation with the maximum $\mathrm{N}_{240}$ rate yielded the highest crude protein and gluten content with the highest sedimentation. The highest grain yield $-7.66 \mathrm{t} \mathrm{ha}^{-1}$ on average, was obtained by fertilising at a rate of $\mathrm{N}_{180}$; however, the difference in grain yield was as little as $0.52 \mathrm{t} \mathrm{ha}^{-1}$ compared to the $\mathrm{N}_{120}$ rate. When fertilising at the rates of $\mathrm{N}_{180}$ and $\mathrm{N}_{240}$ after harvesting, a lot of unused nitrate nitrogen -63.8 and $77.5 \mathrm{~kg} \mathrm{ha}^{-1} \mathrm{~N}-$ $\mathrm{NO}_{3}$ on average, remained in the $0-60 \mathrm{~cm}$ soil layer, while the control plots contained $38.0 \mathrm{~kg} \mathrm{ha}^{-1}$. Assessment of the nutritional value and technological properties of the grain showed that the optimal rate of $\mathrm{N}$ fertiliser for winter wheat was $\mathrm{N}_{180}$, and considering the potential pollution of nitrates to the environment it was $\mathrm{N}_{120}$.
\end{abstract}

Key words: nitrogen fertilisers, mineral nitrogen, yield, grain quality.

\section{Introduction}

One of the topical issues of winter wheat (Triticum aestivum L.) cultivation is the optimization of nitrogen (N) fertilisation (Hlisnikovsky et al., 2020). A lengthy growing period of these plants is about 10 months, $1 / 3$ of which is characterized by intensive growth of plant mass. In Europe, $2 / 3$ of $\mathrm{N}$ is lost in winter and $1 / 3$ - in summer. Nitrogen losses from the soil have a negative impact on the biosphere: soil, groundwater, atmosphere, plants and through them humans and animals. Nitrogen compounds are involved in causing the greenhouse effect and depleting the ozone layer.

The efficient and sustainable use of $\mathrm{N}$ fertilisers offers great potential for reducing greenhouse gas nitrous oxide $\left(\mathrm{N}_{2} \mathrm{O}\right)$ emissions. However, such potential is rarely achieved, as the understanding of what practices (or combinations of practices) lead to reductions in $\mathrm{N}_{2} \mathrm{O}$ emissions without compromising crop yield is still not entirely clear. Balancing usage of $\mathrm{N}$ fertiliser can improve the problems associated with environmental pollution by $\mathrm{N}$ compounds without reducing plant productivity (Sharma, Bali, 2018). Therefore, it is important to distribute $\mathrm{N}$ fertilisers correctly for crops during the growing season (Leghari et al., 2016; Morari et al., 2021). According to trials and production experience, winter wheat is fertilised at a rate of $30 \mathrm{~kg} \mathrm{ha}^{-1} \mathrm{~N}$ in the autumn or not fertilised, if the soil is well cultivated or rich in mineral nitrogen $\left(\mathrm{N}_{\min }\right)$ (Smalstienè et al., 2017).

According to the data of the last five years regarding the winter wheat growth in spring in the south- eastern part of the Baltic Sea basin, it resumes in late March - early April. Starting from this period until the end of May, the total remaining rate of $\mathrm{N}$ fertiliser must be applied in two or three splits (Tabak et al., 2020; Zhao et al., 2020). It is usually calculated for a grain yield of 6 $10 \mathrm{t} \mathrm{ha}^{-1}$ and contains $150-240 \mathrm{~kg} \mathrm{ha}^{-1} \mathrm{~N}$, while assessing soil and cultivar properties (Gaju et al., 2016; Si et al., 2020). However, experiments show that a lower rate of 140-180 kg ha-1 $\mathrm{N}$, which is applied in several splits, is usually sufficient (Staugaitis et al., 2014; Tian et al., 2018). The $\mathrm{N}$ rate is reduced for several reasons. Firstly, $\mathrm{N}$ is required less than estimated for the planned yield as high amounts of $\mathrm{N}_{\min }$ in the soil are replenished in summer due to mineralization of plant residues (Staugaitis et al., 2014; 2015). Secondly, at the end of summer, after winter wheat harvesting areas with higher levels of $\mathrm{N}$ fertilisation remain rich in nitrate nitrogen $\left(\mathrm{N}-\mathrm{NO}_{3}\right)$, which leaches into deeper layers during autumn-winter months thus polluting groundwater (Chen et al., 2014; Sestac et al., 2014).

Nitrogen fertilisation recommendations and legal documents from various countries generally suggest that winter wheat fertilisation should not exceed $210 \mathrm{~kg}$ $\mathrm{ha}^{-1}$ during the growing season and more than $60 \mathrm{~kg} \mathrm{ha}^{-1} \mathrm{~N}$ rate per split (Staugaitis et al., 2015; Tedone et al., 2018). Nitrogen rates recommended by various researchers are spread over a wide range due to soil growing cultivars and the agro-techniques used as well as geographical area, climatic conditions, previous crop and straw ploughing,

Please use the following format when citing the article:

Staugaitis G., Poškus K., Brazienè Z., Paltanavičius V. 2021. Optimization of nitrogen fertilisation of winter wheat. ZemdirbysteAgriculture, 108 (3): 203-208. DOI 10.13080/z-a.2021.108.026 
plant supply with sulphur, etc. (Hawkesford, 2014; Sedlar et al., 2019).

Methodological issues of $\mathrm{N}$ accounting questions, assessing $\mathrm{N}$ uptake by winter wheat with yield, leaching losses, evaporation, etc. (Dhillon et al., 2020) as well as determining the agronomic and physiological efficiency of $\mathrm{N}$ fertilisers are no less relevant research issues (Tabak et al., 2020). It is important to determine the optimal rate of $\mathrm{N}$ fertilisation for winter wheat by evaluating three very important criteria: (1) grain yield, (2) grain quality, and (3) unused $\mathrm{N}-\mathrm{NO}_{3}$ remaining in the soil after harvest (Rasmussen et al., 2015; Tabak et al., 2020).

Therefore, the study hypothesizes that after evaluating the most important factors influencing the productivity of winter wheat it is possible to use less than $210 \mathrm{~kg} \mathrm{ha}^{-1} \mathrm{~N}$ fertilisers using diagnostic methods. It is these criteria that the research is focused on in the current study. The aim of the research was to determine the optimal $\mathrm{N}$ fertiliser rates for winter wheat linking them to grain yield and quality and $\mathrm{N}_{\min }$ concentration in the soil.

\section{Materials and methods}

The experiment was performed in 2018-2020 at the Rumokai Experimental Station of the Lithuanian Research Centre for Agriculture and Forestry. A winter wheat (Triticum aestivum L.) cultivar 'Janne' was grown; it was sown on September 11 in 2018 and September 18 in 2019. In the experiment, four replications of each treatment were used. The experimental plots size was 72 $\mathrm{m}^{2}(12 \times 6 \mathrm{~m})$, harvested area $-36 \mathrm{~m}^{2}(9 \times 4 \mathrm{~m})$. The randomised experimental design was applied. In 2019, the winter wheat was harvested on $30 \mathrm{July}$; in 2020, it was harvested on 10 August.

Winter wheat was fertilised at a rate of $\mathrm{N}_{15} \mathrm{P}_{63} \mathrm{~K}_{10}$ in the autumn before sowing. Complex fertiliser ${ }^{15} \mathrm{PK}$ 5-21-36 was used, treatment rate was $300 \mathrm{~kg} \mathrm{ha}^{-1}$. In the autumn and spring, the winter wheat was fertilised with nitrogen $(\mathrm{N}) \mathrm{kg} \mathrm{ha}^{-1}$ according to the following scheme: 1) $\mathrm{N}_{15}$ (control), 2) $\left.\left.\mathrm{N}_{60(15+45)}, 3\right) \mathrm{N}_{120(15+60+45)}, 4\right) \mathrm{N}$ and 5) $\mathrm{N}_{20(15+45)}$. Fertilisation time and fertiliser rates were chosen according to plant growth stage and amount of fertilisers: in the autumn before sowing, all treatments were fertilised with the same low $\mathrm{N}_{15}$ rate. To have balanced fertilisation in the autumn, $\mathrm{P}_{63}^{15} \mathrm{~K}_{108}$ was applied to all treatments. The $\mathrm{N}$ fertiliser was applied in 1-3 times after resumption of vegetation according to the fertiliser rates. To prevent leaching and evaporation, the rates were split into 1,2 or 3 applications. The plants were fertilised in the spring following the resumption of vegetation at winter wheat growth stage $\mathrm{BBCH} 25-27$ (tillering stage), for the second time - at BBCH 30-31 (beginning of the stem elongation) and for the third time - at BBCH 39 (flag leaf stage). For fertilisation, ammonium nitrate $\left(\mathrm{NH}_{4} \mathrm{NO}_{3}\right)$ was used. Plant protection products against weeds, diseases and pests were used according to the need.

Before harvesting, crop samples were taken from four spots of each plot within $0.25 \mathrm{~m}^{2}$ area for determination of biometric indicators: plant density, total number of productive stems, straw and ear length, number of grains per ear and 1000 grain weight. During harvesting, the grain collected from each experimental plot was weighed separately, and grain moisture content and cleanness were determined. Winter wheat grain yield was expressed at $14 \%$ moisture and absolutely clean mass. The crude protein content in grain was determined by the Kjeldahl method; it was obtained by multiplying the total nitrogen $\left(\mathrm{N}_{\text {tot }}\right)$ by 6.25. Starch content was determined using a polarimeter ATAGO POLAX-2L 086616 (Atago Co., Ltd., Japan), wet gluten - by washing the dough using the Perten Instruments' Gluten Index method (Glutomatic System specified with CSN EN ISO 21415-1), sedimentation - by the Zeleny test (ISO 5529: 2007), mass per hectolitre - using a HLM device Kern 1236 (Pfeuffer GmbH., Germany) compliant with ISO 7971-2:2019).

In order to assess the uptake of $\mathrm{N}$ by plants, the $\mathrm{N}_{\text {tot }}$ concentration in the aboveground mass of growing winter wheat was determined at growth stage $\mathrm{BBCH}$ 32 on 15 April in 2019 and 17 April in 2020 . For this purpose, 10 plants were taken from replications 1 and 2 of each plot, in which the $\mathrm{N}_{\text {to }}$ was determined by wet digestion with concentrated ${ }^{\text {to }} \mathrm{H}_{2} \mathrm{SO}_{4}$ followed by the Kjeldahl method.

Soil samples for agrochemical analyses from winter wheat crops were taken three times a year. The sampling was carried out first after plant growth resumption in early spring at $\mathrm{BBCH} 25$ on 2 April in 2019 and 18 March in 2020). Soil acidity (pH), content of plant available phosphorus $\left(\mathrm{P}_{2} \mathrm{O}_{5}\right)$ and potassium $\left(\mathrm{K}_{2} \mathrm{O}\right)$ as well as humus were determined in the $0-20 \mathrm{~cm}$ layer. The concentration of mineral nitrogen $\left(\mathrm{N}_{\text {min }}\right)$, i.e., $\mathrm{N}-\mathrm{NO}_{3}$, $\mathrm{N}-\mathrm{NH}_{4}$ and their sum, was determined in the $0-30$ and $30-60 \mathrm{~cm}$ layers. Only $\mathrm{N}_{\text {min }}$ was tested for the second and third time; it was determined at growth stage $\mathrm{BBCH}$ 65 on 3 June in 2019 and 17 June in 2020 and during harvesting. For the first time, before $\mathrm{N}$ fertilisation, soil samples were collected from replications 1,2 and 3 of the experimental area, where one composite sample from the $0-20 \mathrm{~cm}$ layer consisted of 20 subsamples, and composite samples from the $0-30$ and $30-60 \mathrm{~cm}$ layers consisted of 9 subsamples. The composite soil samples during the second and third sampling were taken from replications 1 and 3 of each plot. Soil $\mathrm{pH}_{\mathrm{KCl}}$ was determined in $1 \mathrm{M}$ $\mathrm{KCl}$ extraction using the potentiometric method (ISO 10390:2005), ratio 1:5, $\mathrm{P}_{2} \mathrm{O}_{5}$ and $\mathrm{K}_{2} \mathrm{O}$ - by the EgnerRiehm-Domingo (A-L) method, humus - using a carbon analyser after dry combustion compliant with ISO 10694:1995, where the organic carbon concentration was multiplied by $1.724 . \mathrm{N}_{\min }$ content was determined in $1 \mathrm{M}$ $\mathrm{KCl}$ extraction in air-dry samples (ratio 1:5) using the FIAstar 5000 Analyser (Foss Analytical A/S, Denmark).

Soil characterization. The experiment was conducted on a Calcaric Luvisol according to WRB (2014). Soil texture was silt loam on loam and heavy clay loam. The soil $\mathrm{pH}_{\mathrm{KCl}}$ value in the $0-20 \mathrm{~cm}$ layer was within the optimal range for winter wheat, namely $5.9-6.4$, humus $-1.91-2.33 \%$, i.e., the values were low and average. The content of $\mathrm{P}_{2} \mathrm{O}_{5}$ was $148-165 \mathrm{mg} \mathrm{kg}^{-1}$, which was average, and that of $\mathrm{K}_{2}^{5} \mathrm{O}$ was $200-216 \mathrm{mg} \mathrm{kg}^{-1}$, which was high.

In spring, $\mathrm{N}_{\text {min }}$ concentration was distributed across the soil layers as follows: in the $0-30 \mathrm{~cm}$ layer -9.4 $\pm 1.58 \mathrm{mg} \mathrm{kg}^{-1}$ in 2019 and $6.2 \pm 3.45 \mathrm{mg} \mathrm{kg}^{-1}$ in 2020 ; in the $30-60 \mathrm{~cm}$ layer, it was $5.4 \pm 0.62$ and $3.1 \pm 2.04 \mathrm{mg} \mathrm{kg}^{-1}$, respectively. $\mathrm{N}_{\min }$ concentration converted to $\mathrm{kg} \mathrm{ha}^{-1}$ was obtained as follows: in the $0-30 \mathrm{~cm}$ layer, it was $42.5 \pm$ $7.09 \mathrm{~kg} \mathrm{ha}^{-1}$, and in the $30-60 \mathrm{~cm}$ layer $-24.2 \pm 2.77 \mathrm{~kg} \mathrm{ha}^{-1}$ with the total level at $0-60 \mathrm{~cm}-66.7 \pm 9.75 \mathrm{~kg} \mathrm{ha}^{-1}$ in 2019 . In 2020, $\mathrm{N}_{\min }$ content in those layers was $28.0 \pm 15.53,14.0$ \pm 9.16 and $42.0 \pm 24.69 \mathrm{~kg} \mathrm{ha}^{-1}$, respectively. According to the assessment valid in Lithuania (Staugaitis, Vaišvila, $2019), N_{\text {min }}$ content in the soil in spring was low in both years, but in 2020 it was still lower by a third compared to 2019 .

Weather conditions. In 2018-2019 growing season, September was dry and warm with a daily mean air temperature of $15^{\circ} \mathrm{C}$; it was $2.2^{\circ} \mathrm{C}$ above the standard climate normal (SCN). A total of $19.6 \mathrm{~mm}$ of precipitation fell during the month, i.e., it was 3.7 times lower than the $\mathrm{SCN}$. Due to the drought, wheat germination was delayed. In October-November, the daily mean temperature 
values were $1.4^{\circ} \mathrm{C}$ and $0.6^{\circ} \mathrm{C}$ higher than the $\mathrm{SCN}$, and the soil moisture was normal due to sufficient rainfall in October. The plants were well rooted in November, rich in green colour, and their height reached $7-10 \mathrm{~cm}$. The winter in Southwest region of Lithuania was warm and mild: the average daily temperature was $0.03^{\circ} \mathrm{C}$ in December, $-4.1^{\circ} \mathrm{C}$ in January, $1.8^{\circ} \mathrm{C}$ in February and $3.9^{\circ} \mathrm{C}$ in March. The winter wheat overwintered well; plant growth resumed during the third 10-day period of March. The mean air temperature was $8.4^{\circ} \mathrm{C}$ in April and $12.5^{\circ} \mathrm{C}$ in May, and those values were favourable for plant growth (Figure 1).
The plants survived under drought conditions from April to the second 10-day period of May depleting moisture reserves accumulated after the winter; however, during the last week the plants felt moisture scarcity, and plant leaves appeared wilted in the daytime.

It rained profusely in the second half of May, and eventually the precipitation fell in the form of heavy rainfall. June was hot and not rainy. The mean daily temperature of that month was $20.4^{\circ} \mathrm{C}$, or $4.8^{\circ} \mathrm{C}$ higher than the SCN, and the precipitation was only $25.7 \mathrm{~mm}(\mathrm{SCN}-50 \mathrm{~mm})$. During that period, the plants felt a lack of moisture again During the first ten days of July, $60.6 \mathrm{~mm}$ of precipitation fell, and that was enough to restore moisture reserves in the soil. In the second and third 10-day periods, there was

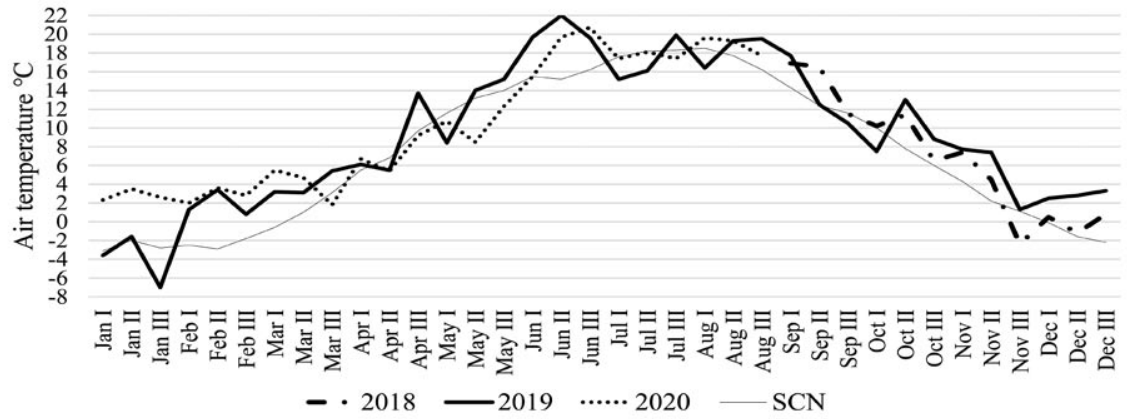

Figure 1. Ten-day mean air temperature during the winter wheat growing season (data of Kybartai Meteorological Station)

little rainfall, and the weather was warm, which allowed normal grain ripening in ears (Figure 2).

2019-2020 growing season. In SeptemberNovember 2019 , it was $1-3^{\circ} \mathrm{C}$ warmer than usual, and the monthly precipitation rate reached $44-47 \mathrm{~mm}$, only in November the rainfall was lower $-13.2 \mathrm{~mm}$. The sown winter wheat germinated evenly, and the plants were 8$12 \mathrm{~cm}$ tall by December. The moisture of the soil plough layer ranged from normal to dryish; however, at that time water evaporation was slow and moisture was sufficient for the plants. The winter was unusually mild: the mean daily temperature values in December-February were $2.8-2.9^{\circ} \mathrm{C}$, and it was a little colder in March $-1.8^{\circ} \mathrm{C}$. The winter wheat overwintered well, and its condition remained almost unchanged during the winter until the beginning of April, when its growth resumed. April and May were cool; however, the amount of precipitation varied significantly - only $2.1 \mathrm{~mm}$ in April and $93.8 \mathrm{~mm}$ in May. Dry March and almost rainless weather in April dried up the soil; therefore, the plants felt a lack of moisture and were less tillered in the second half of April. Rainy May restored soil moisture reserves, and an even rainier June, when $129.4 \mathrm{~mm}$ of rain fell during the month, led to excess moisture in that month and facilitated the high

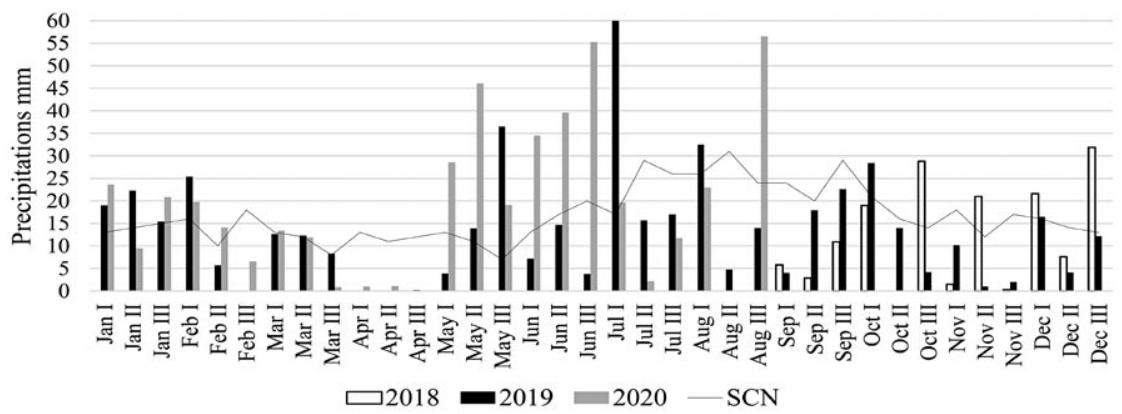

Figure 2. Ten-day rainfall during winter wheat growing season (data of Kybartai Meteorological Station)

spread of Septoria leaf blotch (Zymoseptoria tritici) and less of tan spot (Drechslera tritici-repentis). July and the first 10-day period of August were cool, slightly humid and favourable to grain formation in ears.

Statistical analysis. The trial data were processed using Microsoft Excel, version 14 (Microsoft Corp.) and the analysis of variance (ANOVA) (Raudonius, 2017). The means were compared by using least significant difference (LSD) calculated at the 0.05 probability level (Fisher's LSD test).

\section{Results}

Productivity of winter wheat. Increasing nitrogen $(\mathrm{N})$ fertiliser rates consistently increased winter wheat grain yield (Table 1). The yield was largely determined by the soil fertility, where even with almost no application of $\mathrm{N}$ fertiliser it fluctuated in the range of 4.0-5.2 $\mathrm{t} \mathrm{ha}^{-1}$ in the experimental year and accounted for more than half of the yield compared to that obtained using $\mathrm{N}$ fertiliser. Compared to the control treatment, the fertilising at $\mathrm{N}_{60}$ rate the grain yield increased by an average of $34 \%$, at the rate of $\mathrm{N}_{1}$ - by an additional $21.6 \%$ and $\mathrm{N}_{180}$ - by another $11.3 \%$. Meanwhile, after fertilising at the rate of $\mathrm{N}_{20}$, the yield increase obtained was $5.0 \%$ lower compared to the $\mathrm{N}_{180}$ rate, and that $\mathrm{N}$ rate increased the grain yield most; however, the difference was not significant.

In all experimental plots the plant density was similar; however, the values of other indicators of winter wheat productivity increased with $\mathrm{N}$ fertilisation (Table 2). The two-year average data showed that all fertilisation rates significantly increased the total number of stems. 
Table 1. Influence of nitrogen $(\mathrm{N})$ fertilisation on grain yield of winter wheat

\begin{tabular}{|c|c|c|c|c|c|c|c|}
\hline \multirow[b]{2}{*}{ No. } & \multirow[b]{2}{*}{ Treatment } & \multicolumn{2}{|c|}{2019} & \multicolumn{2}{|c|}{2020} & \multicolumn{2}{|c|}{ 2019-2020 average } \\
\hline & & $\begin{array}{l}\text { yield } \\
\mathrm{t} \mathrm{ha}^{-1}\end{array}$ & $\begin{array}{c}\text { increase } \\
\text { compared } \\
\text { to control } \\
\%\end{array}$ & $\begin{array}{l}\text { yield } \\
\mathrm{t} \mathrm{ha}^{-1}\end{array}$ & $\begin{array}{c}\text { increase } \\
\text { compared } \\
\text { to control } \%\end{array}$ & $\begin{array}{l}\text { yield } \\
\mathrm{t} \mathrm{ha}^{-1}\end{array}$ & $\begin{array}{c}\text { increase } \\
\text { compared } \\
\text { to control } \\
\%\end{array}$ \\
\hline 1. & $\mathrm{~N}_{15}$ (control) & $5.18 \mathrm{a}$ & - & $4.00 \mathrm{a}$ & - & $4.59 \mathrm{a}$ & - \\
\hline 2. & $\mathrm{~N}_{60(15+45)}$ & $6.40 \mathrm{~b}$ & 23.5 & $5.90 \mathrm{~b}$ & 47.5 & $6.15 \mathrm{~b}$ & 34.0 \\
\hline 3. & $\mathrm{~N}_{120(15+60+45)}^{00(15+45)}$ & $6.97 \mathrm{c}$ & 34.6 & $7.31 \mathrm{c}$ & 82.7 & $7.14 \mathrm{c}$ & 55.6 \\
\hline 4. & $\mathrm{~N}_{180(15+90+45+30)}^{120(15+00+45)}$ & $7.59 \mathrm{~d}$ & 46.5 & $7.73 \mathrm{~d}$ & 93.3 & $7.66 \mathrm{~d}$ & 66.9 \\
\hline 5. & $\mathrm{~N}_{240(15+120+45+60)}$ & $7.27 \mathrm{~cd}$ & 40.3 & $7.58 \mathrm{~d}$ & 89.5 & $7.43 \mathrm{~d}$ & 61.9 \\
\hline
\end{tabular}

Note. Differences between the averages of treatments marked by not the same letter are significant at $P<0.05$.

Table 2. Influence of nitrogen (N) fertilisation on productivity indicators of winter wheat (2019-2020)

\begin{tabular}{|c|c|c|c|c|c|c|}
\hline No. & Treatment & $\begin{array}{c}\text { Plant density, } \\
\text { plants } \\
\text { per } \mathrm{m}^{2}\end{array}$ & $\begin{array}{c}\text { Total } \\
\text { number } \\
\text { of stems } \\
\text { per } \mathrm{m}^{2}\end{array}$ & $\begin{array}{l}\text { Straw } \\
\text { length } \\
\mathrm{cm}\end{array}$ & $\begin{array}{l}\text { Ear } \\
\text { length } \\
\mathrm{cm}\end{array}$ & $\begin{array}{l}\text { Number } \\
\text { of grains } \\
\text { per ear }\end{array}$ \\
\hline $\begin{array}{l}1 . \\
2 . \\
3 . \\
4 . \\
5 .\end{array}$ & $\begin{array}{l}\mathrm{N}_{15} \text { (control) } \\
\mathrm{N}_{60(15+45)} \\
\mathrm{N}_{120(15+60+45)} \\
\mathrm{N}_{180(15+90+45+30)} \\
\mathrm{N}_{240(15+120+45+60)}\end{array}$ & $\begin{array}{l}258 \mathrm{a} \\
267 \mathrm{a} \\
244 \mathrm{a} \\
257 \mathrm{a} \\
241 \mathrm{a} \\
\end{array}$ & $\begin{array}{l}560.7 \mathrm{a} \\
584.7 \mathrm{~b} \\
643.7 \mathrm{c} \\
679.0 \mathrm{~d} \\
654.7 \mathrm{c} \\
\end{array}$ & $\begin{array}{l}61.0 \mathrm{a} \\
66.1 \mathrm{~b} \\
67.2 \mathrm{bd} \\
70.0 \mathrm{c} \\
68.1 \mathrm{~d}\end{array}$ & $\begin{array}{l}7.3 \mathrm{a} \\
8.0 \mathrm{~b} \\
8.4 \mathrm{c} \\
8.6 \mathrm{c} \\
8.1 \mathrm{bd}\end{array}$ & $\begin{array}{l}36.9 \mathrm{a} \\
42.7 \mathrm{~b} \\
44.4 \mathrm{c} \\
45.9 \mathrm{c} \\
41.6 \mathrm{~b}\end{array}$ \\
\hline
\end{tabular}

Explanation under Table 1

The fertilisation rate of $\mathrm{N}_{180}$ resulted in the highest total number of stems of winter wheat. The plants were lusher resulting in longer straw and ear length and a higher number of grains per ear. Meanwhile, when the plants were fertilised with both higher and lower $\mathrm{N}$ rates, the values of these indicators decreased, and the lowest yields were obtained from plants grown in the plots with zero $\mathrm{N}$ application. These regularities were obtained during both experimental years.

Winter wheat grain quality. According to the two-year average data, almost the same 1000 grain weight was obtained after fertilisation at the rates of $\mathrm{N}_{15}, \mathrm{~N}_{60}$, $\mathrm{N}_{120}$ and $\mathrm{N}_{180}$ (Table 3). Fertilisation rate of $\mathrm{N}_{240}$ resulted in 1000 grain weight loss. The weight per hectolitre was increased by increasing rates of $\mathrm{N}$ fertilisers, and there was the highest and significant increase after fertilisation at the rates of $\mathrm{N}_{.180}$ and $\mathrm{N}_{240}$. While summarizing both these indicators, it can be stated that the plants fertilised with $\mathrm{N}_{180}$ had the highest grain weight.

${ }^{180}$ Nitrogen fertilisers regularly reduced the starch concentration in grain: it was the highest in the grain fertilised with $\mathrm{N}_{15}$ and the lowest at the rates of $\mathrm{N}_{180}$ and $\mathrm{N}_{240}$. In contrast to starch, $\mathrm{N}$ fertilisers increased the concentration of crude protein in grain. According to the two-year average data, it increased within a very wide range - actually, from $9.0 \%$ in the grain fertilised with $\mathrm{N}_{15}$ to $13.7 \%$ in that fertilised at the maximum rate of $\mathrm{N}_{240}$. However, fertilisation with $\mathrm{N}_{180}$ resulted in a crude protein concentration of $13.3 \%$ and did not lag far behind from the grain fertilised at the maximum $\mathrm{N}$ rate (the difference was significant). Nitrogen fertilisation improved the technological properties of winter wheat grain. Sedimentation without $\mathrm{N}$ fertilisation was $19.3 \%$, and after fertilisation at the rate of $\mathrm{N}_{240}$ it increased to $50.8 \%$; gluten content increased from $15.9 \%$ to $27.8 \%$, respectively.

Concentration of mineral $N$ in the soil. Research interests were not only grain yield and its quality, but also $\mathrm{N}_{\min }$ concentration in the soil after all the $\mathrm{N}$ fertilisations. $\mathrm{N}_{\min }^{\min }$ concentration in the $0-30 \mathrm{~cm}$ layer at winter wheat growth stage $\mathrm{BBCH} 65$ was relatively low - 1.42-6.29 $\mathrm{mg} \mathrm{kg}^{-1}$ after fertilisation at the rates of $\mathrm{N}_{15}, \mathrm{~N}_{60}$ and $\mathrm{N}_{120}$ in 2019 and 2020 (Table 4). It was

Table 3. Influence of nitrogen (N) fertilisation on grain quality of winter wheat (2019-2020)

\begin{tabular}{|c|c|c|c|c|c|c|c|}
\hline No. & Treatment & $\begin{array}{c}\text { Weight per } \\
\text { hectolitre } \\
\mathrm{kg} \mathrm{hl}\end{array}$ & $\begin{array}{c}1000 \text { grain } \\
\text { weight } \\
\text { g }\end{array}$ & $\begin{array}{c}\text { Starch } \\
\%\end{array}$ & $\begin{array}{l}\text { Crude } \\
\text { protein } \\
\%\end{array}$ & $\underset{\%}{\text { Sedimentation }}$ & $\begin{array}{c}\text { Gluten } \\
\%\end{array}$ \\
\hline 1. & $\mathrm{~N}_{15}$ (control) & $77.7 \mathrm{a}$ & $39.7 \mathrm{a}$ & $69.7 \mathrm{a}$ & $9.0 \mathrm{a}$ & $19.3 \mathrm{a}$ & $15.9 \mathrm{a}$ \\
\hline 2. & $\mathbf{N}_{60(15+45)}$ & $78.2 \mathrm{a}$ & $39.2 \mathrm{a}$ & $69.2 \mathrm{~b}$ & $9.8 \mathrm{~b}$ & $23.5 \mathrm{~b}$ & $17.5 \mathrm{~b}$ \\
\hline 3. & $\mathrm{~N}_{120(15+60+45)}$ & $79.3 \mathrm{~b}$ & $39.3 \mathrm{a}$ & $68.8 \mathrm{c}$ & $11.7 \mathrm{c}$ & $37.0 \mathrm{c}$ & $22.2 \mathrm{c}$ \\
\hline 4. & $\mathrm{~N}_{180(15+90+45+30)}$ & $80.1 \mathrm{c}$ & $39.1 \mathrm{ab}$ & $67.9 \mathrm{~d}$ & $13.3 \mathrm{~d}$ & $47.0 \mathrm{~d}$ & $26.6 \mathrm{~d}$ \\
\hline 5. & $\mathrm{~N}_{240(15+120+45+60)}$ & $80.4 \mathrm{c}$ & $38.0 \mathrm{~b}$ & $67.8 \mathrm{~d}$ & $13.7 \mathrm{e}$ & $50.8 \mathrm{c}$ & $27.8 \mathrm{c}$ \\
\hline
\end{tabular}

Explanation under Table 1

significantly higher after fertilisation with $\mathrm{N}_{180}-9.66-$ $12.99 \mathrm{mg} \mathrm{kg}^{-1}$ and very high after fertilisation with $\mathrm{N}_{24}$ $-9.36-22.97 \mathrm{mg} \mathrm{kg}^{-1}$. The differences obtained depended on both $\mathrm{N}$ fertiliser rates and the year. In $2019, \mathrm{~N}_{\mathrm{m}}$ concentration was significantly higher when fertilising with $\mathrm{N}_{180}$ and $\mathrm{N}_{240}$.

${ }^{80}$ Almost two months later, i.e., after harvesting, $\mathrm{N}_{\mathrm{m}}$ concentration not only did not decrease but even increased, especially in 2020. This might have been influenced by many factors, but apparently the most important was organic matter mineralization in the soil during the summer (Staugaitis et al., 2015). However, the essential point is that when fertilising with $\mathrm{N}_{180}$ and especially with $\mathrm{N}_{240}$, high $\mathrm{N}_{\min }$ contents remain in the $0-60 \mathrm{~cm}$ layer during harvesting - according to the average two-year data, those were 17.65 and $20.10 \mathrm{mgkg}^{-1}$, respectively.

Nitrogen concentration in plants during winter wheat growth. The total $\mathrm{N}$ content in the aboveground part of wheat at growth stage BBCH 32 was determined. Its optimal concentration at this stage of cultivation is $2.4-4.3 \%$ (dry matter) (Breuer et al., 2003). The results of the experiment showed that $\mathrm{N}$ concentration in 2019 was at the lower end of the optimum and, according to $\mathrm{N}$ fertiliser treatments, it was distributed as follows: $\mathrm{N}_{15}$ $2.93 \%, \mathrm{~N}_{60}-3.14 \%, \mathrm{~N}_{120}-3.37 \%, \mathrm{~N}_{180}-3.45 \%$ and $\mathrm{N}_{240}$ $-3.29 \%\left(\mathrm{LSD}_{05}=0.377\right)$. Here, significant differences were obtained only between the treatments with $\mathrm{N}_{15}$ and those with $\mathrm{N}_{120}$ and higher rates. In $2020, \mathrm{~N}$ concentration 
Table 4. Influence of nitrogen $(\mathrm{N})$ fertilisation on mineral $\mathrm{N}$ concentration in soil, $\mathrm{mg} \mathrm{kg}^{-1}$

\begin{tabular}{|c|c|c|c|c|c|c|c|c|c|}
\hline \multirow{3}{*}{ No. } & \multirow{3}{*}{ Treatment } & \multicolumn{4}{|c|}{ After all $\mathrm{N}$ applications (BBCH 65) } & \multicolumn{4}{|c|}{ At harvesting } \\
\hline & & \multicolumn{2}{|c|}{$0-30 \mathrm{~cm}$} & \multicolumn{2}{|c|}{$0-60 \mathrm{~cm}$} & \multirow{2}{*}{$\begin{array}{c}0-30 \mathrm{~cm} \\
2019 \\
\end{array}$} & \multicolumn{3}{|c|}{$0-60 \mathrm{~cm}$} \\
\hline & & 2019 & 2020 & 2019 & 2020 & & 2020 & 2019 & 2020 \\
\hline 1. & $\mathrm{~N}_{15}$ (control) & $1.42 \mathrm{a}$ & $4.65 \mathrm{a}$ & $2.88 \mathrm{a}$ & $7.18 \mathrm{a}$ & $6.31 \mathrm{a}$ & $7.39 \mathrm{a}$ & $8.88 \mathrm{a}$ & $14.23 \mathrm{a}$ \\
\hline 2. & $\mathrm{~N}_{60(15+45)}$ & $2.76 \mathrm{ab}$ & $5.28 \mathrm{a}$ & $4.31 \mathrm{a}$ & $7.86 \mathrm{a}$ & $7.33 \mathrm{a}$ & $7.76 \mathrm{a}$ & $9.86 \mathrm{a}$ & $13.99 \mathrm{a}$ \\
\hline 3. & $\mathrm{~N}_{120(15+60+45)}$ & $6.29 \mathrm{~b}$ & $4.59 \mathrm{a}$ & $10.83 \mathrm{~b}$ & $7.06 \mathrm{a}$ & $12.38 \mathrm{a}$ & $6.82 \mathrm{a}$ & $17.39 \mathrm{~b}$ & $14.37 \mathrm{a}$ \\
\hline 4. & $\mathrm{~N}_{180(15+90+45+30)}$ & $12.99 \mathrm{c}$ & $9.66 \mathrm{~b}$ & $15.30 \mathrm{c}$ & $13.14 \mathrm{~b}$ & $17.27 \mathrm{a}$ & $7.79 \mathrm{a}$ & $20.90 \mathrm{bc}$ & $14.40 \mathrm{a}$ \\
\hline 5. & $\mathrm{~N}_{240(15+120+45+60)}$ & $22.97 \mathrm{~d}$ & $9.36 \mathrm{~b}$ & $32.27 \mathrm{~d}$ & $12.75 \mathrm{~b}$ & $18.48 \mathrm{ab}$ & $10.18 \mathrm{c}$ & $23.51 \mathrm{c}$ & $16.68 \mathrm{~b}$ \\
\hline
\end{tabular}

Explanation under Table 1

in plants was lower in all treatments: $\mathrm{N}_{15}-2.56 \%, \mathrm{~N}_{60}$ $-2.59 \%, \mathrm{~N}_{120}-2.65 \%, \mathrm{~N}_{180}-2.96 \%$ and $\mathrm{N}_{240}-2.93 \%$ $\left(\mathrm{LSD}_{05}=0.367\right)$. Here, significant differences were obtained between the treatments with $\mathrm{N}_{15}$ and those with $\mathrm{N}_{180}$ and $\mathrm{N}_{240}$. Thus, in both experimental years, the $\mathrm{N}$ concentration in winter wheat was within the optimum range, and significant $\mathrm{N}$ concentration in plants was obtained only between the winter wheat fertilised at a rate of $\mathrm{N}_{15}$ and higher $\mathrm{N}$ rates.

Nitrogen uptake by winter wheat. The $\mathrm{N}$ content removed with grain yield and straw by fertilising $\mathrm{N}_{15}$ in 2019 was $111 \mathrm{~kg} \mathrm{ha}^{-1}, \mathrm{~N}_{60}-145 \mathrm{~kg} \mathrm{ha}^{-1}, \mathrm{~N}_{120}-169 \mathrm{~kg} \mathrm{ha}^{-1}$, $\mathrm{N}_{180}-193 \mathrm{~kg} \mathrm{ha}^{-1}$ and $\mathrm{N}_{240}-196 \mathrm{~kg} \mathrm{ha}^{-120}$; in $2020-71$, $115,156,195$ and $191 \mathrm{~kg} \mathrm{ha}^{-1}$, respectively. This shows that when fertilising with the minimum $\mathrm{N}_{15}$ rate, plants without $\mathrm{N}$ fertilisers still absorbed 56-96 kg ha-1 $\mathrm{N}$ from the soil in experimental years. This is an indicator of well-cultivated and fertile soil. When fertilising with $\mathrm{N}_{60}$, $\mathrm{N}_{120}$ and $\mathrm{N}_{180}$ fertiliser rates, less $\mathrm{N}$ was absorbed from the soil, but all applied fertiliser $\mathrm{N}$ was used; using the rate of $\mathrm{N}_{240}$ - part of the fertiliser left unused $\mathrm{N}$ in the soil - a two-year average of $46 \mathrm{~kg} \mathrm{ha}^{-1}$. This is a large amount of irrationally used N (Figure 3).

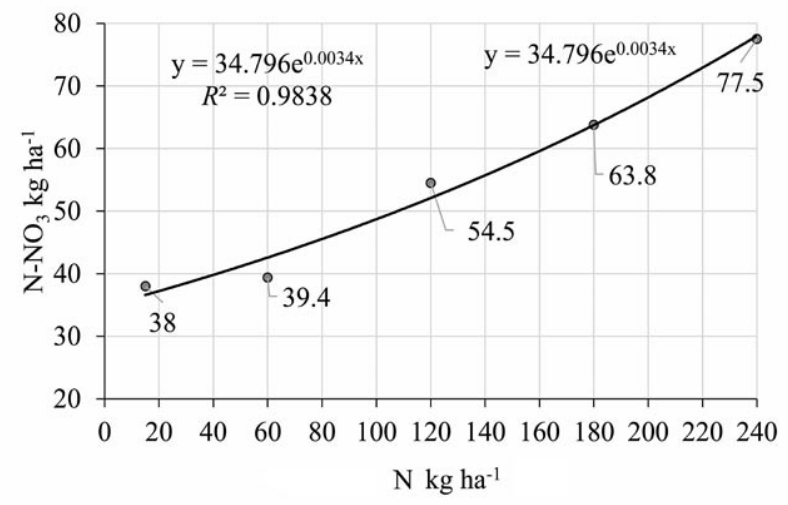

$\mathrm{y}=34.796 \mathrm{e}^{0,0034 \mathrm{x}}-$ the regression equation; $R^{2}-$ the coefficient of determination

Figure 3. Influence of nitrogen $(\mathrm{N})$ fertiliser rates on nitrate nitrogen $\left(\mathrm{N}-\mathrm{NO}_{3}\right)$ content remaining in the $0-60 \mathrm{~cm}$ soil layer after winter wheat harvesting (2019-2020)

\section{Discussion}

During the experiment, nitrogen fertilisers improved the nutritional value and technological properties of winter wheat grain. Application of the maximum $\mathrm{N}_{240}$ rate yielded the highest levels of crude protein and gluten with the highest sedimentation. This is pointed out by other researchers arguing that higher $\mathrm{N}$ fertiliser rates are more important for grain yield and quality and especially in this latitude, where there are fewer sunny days, and the climate is maritime and continental (Juchnevičienè et al., 2016). Meanwhile, the highest grain yield was obtained by the application of a lower $\mathrm{N}_{180}$ rate, and the amount of $\mathrm{N}$ uptake by winter wheat was $194 \mathrm{~kg} \mathrm{ha}^{-1}$. It is also a high $\mathrm{N}$ rate, as in many countries $\mathrm{N}_{170}$ is the maximum allowable rate for the use of organic fertilisers (Jadczyszyn, 2015; Staugaitis et al., 2015; Düngung im Obstbau, 2018). Having determined that the $\mathrm{N}_{180}$ rate is the maximum one in the experiment let us examine the effect of a significantly lower $\mathrm{N}_{120}$ rate for winter wheat. Compared to $\mathrm{N}_{180}$, the yield was $7 \%$ lower, and the difference in grain yield was $0.52 \mathrm{t} \mathrm{ha}^{-1}$. However, when fertilising with $\mathrm{N}_{10}$ rate, nitrogen use efficiency was higher $-1 \mathrm{~kg}$ of fertiliser yielded $24.3 \mathrm{~kg}$ of grain, while $\mathrm{N}_{180}-18.6 \mathrm{~kg}$, and this is the focus of other researchers (Hawkesford, 2014; Tabak et al., 2020). However, when fertilising with $\mathrm{N}_{180}$ and $\mathrm{N}_{240}$ rates, after harvesting a lot of unused $\mathrm{N}-\mathrm{NO}_{3}$ remained in the $0-60 \mathrm{~cm}$ soil layer (Figure 3 ). This is a potential risk of nitrate groundwater pollution when fertilised with such $\mathrm{N}$ rates (Sestak et al., 2014).

It was assumed that focusing on the nutritional value, technological properties and grain yield, the optimal rate of $\mathrm{N}$ fertiliser for winter wheat would be $\mathrm{N}_{180}$. Depending on the potential nitrate pollution of the environment, this rate will decrease to $\mathrm{N}_{120}$; the quality of grain would decrease to some extent.

\section{Conclusions}

1. In Southwest region of Lithuania, in a Calcaric Luvisol, nitrogen (N) fertilisers improved the nutritional value and technological properties of winter wheat grain. The application of the maximum $\mathrm{N}_{240}$ rate yielded the highest content of crude protein and gluten with the highest sedimentation.

2. At the $\mathrm{N}_{180}$ rate of fertilisation, the plants used an average of $194 \mathrm{~kg} \mathrm{ha}^{-1} \mathrm{~N}$, and the highest grain yield was obtained amounting to on average $7.66 \mathrm{tha}^{-1}$.

3. When fertilising with $\mathrm{N}_{180}$ and $\mathrm{N}_{240}$, a lot of unused nitrate nitrogen $\left(\mathrm{N}-\mathrm{NO}_{3}\right)$ remained in the $0-60 \mathrm{~cm}$ soil layer after harvesting -63.8 and $77.5 \mathrm{~kg} \mathrm{ha}^{-1}$ on average, while in the plots fertilised with $\mathrm{N}_{15}-38.0 \mathrm{~kg} \mathrm{ha}^{-1}$.

4. Assessment of the nutritional value, technological properties and grain yield of winter wheat showed that the optimal rate of $\mathrm{N}$ fertilisation for winter wheat in was $\mathrm{N}_{180}$ and taking into account the potential nitrate pollution of the environment $-\mathrm{N}_{120}$.

Received 15032021

Accepted 14062021

\section{References}

Breuer J., König V., Merkel D., Olfs H. W., Steingrobe B., Stimpfl E., Wissemeier A., Zorn W. 2003. Plant analysis for the diagnosis of the nutritional status of crops, $113 \mathrm{~S}$. (in German).

Chen X., Cui Z., Fan M., Vitousek P., Zhao M., Ma W., Wang Z., Zhang W., Yan X., Yang J. 2014. Producing more grain with lower envirnnmental coste Nature 514: 486-491. https://doi.org/10.17221/315/2019-PSE

Dhillon J., Eickhott E., Aula L., Umara P., Weymeyer G., Nambi E., Oyebiyi F., Carpenter T., Raun W. 2020. Nitrogen management impact on winter wheat grain yield and estimated nlant nitrogen loss A gronnmy Inurnal, 112 (1): 564-577. https://doi.org/10.1002/agj2.20107 
Düngung im Obstbau - Leitfaden. 2018. Staatliche Lehr- und Versuchsanstalt für Wein- und Obstbau Weinsberg. BadenWürttemberg (in German). https://lvwo.landwirtschaftbw.de/pb/,Lde/Startseite/Fachinformationen/ Duengung+im+Obstbau+-+ein+Leitfaden

Gaju O., DeSilva J., Carvalho P., Hawkesford M. J., Griffiths S., Greenland A., Foulkes M. J. 2016. Leaf photosynthesis and associations with grain yield, biomass and nitrogen use efficiency in landraces, synthetic-derived lines and cultivars in wheat. Field Crons Research, 193: 1-15. https://doi.org/10.1016/j.fcr.2016.04.018

Hawkestord M. J. 2014. Keducing the reliance on nitrogen fertiliser for wheat nroduction. Inurnal of Cereal Science, 59 (3): 276-283. https://doi.org/10.1016/j.jcs.2013.12.001

Hlisnikovsky L., Menšik L., Kunzova E. 2020. The development of winter wheat yield and quality under different fertiliser regimes and soil-climatic conditions in the Czech Renublic. Agronomy, 10 (1160): 1-17. https://doi.org/10.3390/agronomy 10081160

Jadczyszyn I. (ed.). 2015. Dobre praktyki rolnicze na obszarach szczególnie narażonych (OSN) na azotany pochodzenia rolniczego. Centrum Doradztwa Rolniczego, Brwinow, Poland, 106 p. (in Polish). http://iung.pl/dpr/ Mat_szkoleniowe/publ_azotany.pdf

Juchnevičienè A., Vagusevičienè I., BrazaitytėA., Duchovskis P. 2016. The dependence of quality indicators of winter wheat grain on fertilisation with nitrogen fertilisers. Žemès îkin mokslai, 23 (2): 47-55 (in I ithuanian). https://doi.org/10.6001/zemesukiomokslai.v23i2.3296

Leghari S. J., Wahocho N. A., Laghari G. M., Laghari A. H., Bhabhan G. M., Talpur K. H., Lashari A. A. 2016. Role of nitrogen for plant growth and development: a review. Advances in Environmental Biology, 10 (9): 209-218. https://www.researchgate.net/publication/309704090 Role_of_Nitrogen_for_Plant_Growth_and_Development_A review

Morari F., Zanella V. Gobbo S., Bindi M., Sartori L., Pasqui M., Mosca G. 2021. Coupling proximal sensing, seasonal forecasts and crop modelling to optimize nitrogen variable rate application in durum wheat. Precision Agriculture, 22: 75-98. https://doi.org/10.1007/s11119-020-09730-6

Rasmussen I. S., Dresbøll D. B., Thorup-Kristensen K. 2015. Winter wheat cultivars and nitrogen $(\mathrm{N})$ fertilization - effects on root growth, $\mathrm{N}$ uptake efficiency and $\mathrm{N}$ use efficiency. Furnean Journal of Agronomy, 68: 38-49. https://doi.org/10.1016/j.eja.2015.04.003

Raudonius S. 2017. Application of statistics in plant and crop research: important issues. 7emdirhyste-A griculture 104 (4): 377-382. https://doi.org/10.13080/z-a.2017.104.048

Sedlar O., Balik J., Kulhanek M., Cerny J., Suran P. 2019. Sulphur nutrition index in relation to nitrogen uptake and quality of winter wheat grain. Chilean Journal of A gricultural Research 79 (3): 486-492.

https://doi.org/10.4067/S0718-58392019000300486
Sestak I., Mesic M., Zagorelek Z., Kisic I., Basic F. 2014. Winter wheat agronomic traits and nitrate leaching under variable nitrogen fertilisation. Plant, Soil and Environment, 60 (9): 394-400. https://doi.org/10.17221/188/2014-PSE

Sharma L. K., Bali S. K. 2018. A review of methods to improve nitrogen use efficiency in agriculture. Sustainability, 10: 51. https://doi.org/10.3390/su10010051

Si Z., Zain M., Li S., Liu J., Liang Y., Gao Y., Duan A. 2020. Optimizing nitrogen application for dripirrigated winter wheat using the DSSAT-CERES-Wheat model. Agricultural Water Management, 244: 106592. https://doi.org/10.1016/j.agwat.2020.106592

Smalstienè V., Pranckietienè I., Dromantienè R., Šidlauskas G. 2017. The influence of different nitrogen forms and application time on winter wheat. Žemès ūkio mokslai, 24 (3): 81-90 (in Lithuanian). https://doi.org/10.6001/zemesukiomokslai.v24i3.3554

Staugaitis G. Vaišvila Z. 2019. Soil agrochemical research. Lithuanian Research Centre for Agriculture and Forestry, 111 p. (in Lithuanian).

Staugaitis G., Žičkienė L., Mažvila J., Arbačiauskas J., Šumskis D., Masevičienè A., Staugaitienè R. 2014. The regularities of mineral nitrogen distribution in Lithuania's soils in spring. Zemdirbyste-Agriculture, 102 (4): 371-380. https://doi.org/10.13080/z-a.2015.102.047

Staugaitis G., Zičkienė L., Arbačiauskas J., Mažvila J., Vaišvila Z., Šumskis D., Masevičienè A. 2015. Observation of mineral nitrogen variation. Innovative Solutions of Soil and Agrochemistry Science, p. 162-167 (in Lithuanian).

Tabak M., Lepiarczyk A., Filipek-Mazur B., Lisowska A. 2020. Efficiency of nitrogen fertilisation of winter wheat depending on sulfur fertilisation. Agronomy, 10 (1304): 1-17. https://doi.org/10.3390/agronomy10091304

Tedone L., Alhajj Ali S., Verdini L., De Mastro G. 2018. Nitrogen management strategy for optimizing agronomic and environmental performance of rainfed durum wheat under Mediterranean climate. Journal of Cleaner Production. 172: 2058-2074. https://doi.org/10.1016/j.jclepro.2017.11.215

Tian Z. W., Liu X. X., Gu S. L., Yu J. H., Zhang L., Zhang W. W., Jiang D., Cao W. X., Dai T. B. 2018. Postponed and reduced basal nitrogen application improves nitrogen use efficiency and plant growth of winter wheat. Journal of Integrative Agriculture, 17: 2648-2661. https://doi.org/10.1016/S2095-3119(20)63407-4

WRB. 2014. World reference base for soil resources. World Soil Resources Reports No. 106. FAO, 189 p. http://www. fao.org/3/a-i3794en.pdf

Zhao W., Shan Z., Li J., Li Y. 2020. Effects of fertigation splits through center pivot on the nitrogen uptake, yield, and nitrogen use efficiency of winter wheat grown in the North China Plain. Agricultural Water Management, 240: 106291. https://doi.org/10.1016/j.agwat.2020.106291

\title{
Žieminių kviečių tręšimo azotu optimizavimas
}

\author{
G. Staugaitis, K. Poškus, Z. Brazienė, V. Paltanavičius
}

Lietuvos agrarinių ir miškų mokslų centras

\section{Santrauka}

2019-2020 m. karbonatiniame išplautžemyje buvo atliktas eksperimentas su žieminiais kviečiais (Triticum aestivum L.), augintais taikant intensyvią auginimo technologiją. Tyrimo tikslas - nustatyti žieminiams kviečiams optimalias azoto trąšų normas, jas susiejant su grūdų derliumi bei kokybe ir mineralinio azoto koncentracija dirvožemyje.

Tyrimo duomenys parodè, kad azoto trąšos pagerino žieminių kviečių grūdų mitybinę vertę ir technologines savybes. Patręšus maksimaliai $\mathrm{N}_{240}$, daugiausia gauta žalių baltymų ir glitimo. Didžiausias grūdų derlius gautas patręšus $\mathrm{N}_{180}$ - vidutiniškai 7,66 tha ${ }^{-1}$, tačiau grūdų derliaus skirtumas, lyginant su $\mathrm{N}_{120}$ trąšų, sudarè tik $0,52 \mathrm{tha}^{-1}$. Patręšus $\mathrm{N}_{180}^{180}$ ir $\mathrm{N}_{240}$, po derliaus nuėmimo dirvožemio $0-60 \mathrm{~cm}$ sluoksnyje liko daug nesunaudoto nitratinio azoto $\left(\mathrm{N}-\mathrm{NO}_{3}\right)$ - vidutiniškai 63,8 ir $77,5 \mathrm{~kg} \mathrm{ha}^{-1}$, o kontroliniuose laukeliuose - 38,0 $\mathrm{kg} \mathrm{ha}^{-1}$. Vertinant grūdų mitybinę vertę ir technologines savybes, žieminiams kviečiams optimali azoto trąšų norma yra $\mathrm{N}_{180}$, o atsižvelgus ị potencialią aplinkos taršą nitratais $-\mathrm{N}_{120}$.

Reikšminiai žodžiai: azoto trąšos, mineralinis azotas, derlingumas, grūdų kokybė. 